\title{
From Confinement to College: Impacts of College in Prison Education on Formerly Incarcerated Persons of East Jersey State Prison, New Jersey
}

\author{
Sanford Sandy Shevack* \\ Department of Sociology and Criminal Justice, William Paterson University, USA
}

*Corresponding author: Sanford Sandy Shevack, Department of Sociology and Criminal Justice, William Paterson University, USA.

Received Date: August 14, 2019

Published Date: September 16, 2019

\section{Abstract}

Formerly incarcerated people re-entering society find their convictions can make obtaining employment nearly impossible [1]. Usually, they are return to the same impoverished communities in which they lived prior to incarceration. Society's overreliance on prisons as a solution to reduce crime has made incarceration a "normal" life event in many poor neighborhoods, and issues of race and income inequalities are aggravating factors within these disenfranchised communities (Center for Prison Education [CPE], n.d.). The probability of a family living in poverty increases by nearly $40 \%$ while the father is in prison, and children of incarcerated parents are at greater risk of developmental delays, behavioral problems, academic failure, and are more likely to become prisoners themselves [2].

Earning a college degree has significant socioeconomic advantages. As of 2015, workers with less than a high school diploma earned an average $\$ 493$ a week compared to an average $\$ 798$ a week for workers with an associate's degree and an average $\$ 1,137$ a week for workers with a bachelor's degree [3].

This study assessed the impact of college education on formerly incarcerated men of East Jersey State Prison of the New Jersey Department of Corrections. The research examined how higher education courses taught within penal institutions affected recidivism and helped ex-offenders reintegrate into their communities. The college program is known as the New Jersey Scholarship and Transformative Education in Prisons (NJ STEP).

\section{Problem Statement}

In the U.S., more than 2 million people are incarcerated at any given time, a rate that exceeds any other nation [4]. The State of New Jersey's prison population totals almost 22,000 men and women. Nearly $53 \%$ of released inmates are re-arrested while $31.1 \%$ return to prison within 3 years [5].

The stigma of being referred to as an ex-convict has multiple effects for returning citizens who seek to fully participate in society. Negative labeling often creates a poor self-image. The person expects others will not accept or respect him/her. Psychological research shows stigmatized individuals have difficulty in relationships with others, which may result in depression and anti-social behaviors. As an incarcerated person approaches his/her date of release, these anxieties can intensify. The anticipation of being ostracized may lead to stress, fear, and alienation. Inmates are aware they are temporarily-in some jurisdictions, permanently-denied voting rights, barred from public housing, financial aid, and employment [6].
Stigmatization has been studied through the perspective of Labeling Theory. This theory states that once a person has been formally stigmatized as a convict, felon, ex-con, s/he may internalize the stereotypical image and conform to anti-social attitudes projected upon him/her. This reinforces the belief of many that ex-offenders are not worthy of opportunities to reintegrate into society.

Race, ethnicity, and poverty are additional intersecting factors that pose barriers for formerly incarcerated people. African Americans and Hispanics represent $13.7 \%$ and $19 \%$ of New Jersey's population respectively. As of 2015, 19.7\% of African Americans and $21.2 \%$ of Hispanics in New Jersey live below the poverty line. New Jersey's prison population is 61\%. African American (11,965inmates) and 13.7\% Hispanic (3,118 inmates) [5]. According to the 2007 Annual Report on Human Rights, African American males were incarcerated at higher rates than any race (Nation Behind Bars, Human Rights Watch, 2008). 
Returning citizens most often lack the education required to obtain gainful employment. President Barack Obama urged expansion of community college opportunities and stated that an associate's degree has become a critical credential for an individual's participation in the information and service-based economy [7]. Thirty-seven percent of formerly incarcerated people released from New Jersey prisons have no high school diploma or general education diploma (GED), and 92\% lack a college degree [5].

\section{Purpose of the Study}

The central focus of this study was to examine the influences of the college-in-prison education program at East Jersey State Prison in New Jersey to help mitigate the challenges of being labeled and stigmatized following release into communities. The study examined if college educated returning citizens have higher rates of employment, lower recidivism rates, and what impact the collegein-prison experience, if any, has on their families.

\section{Significance of the Study}

The study revealed the personal insights of those who experience college education while in prison. Public opinions can influence social policies. This study does not claim that such college programs are the answer to solve the problem of mass incarceration but, should be examined as a strategy to reduce recidivism and ameliorate the challenges of re-integration following incarceration. This knowledge may be used by college/prison administrators, professors, students, law makers, and advocacy groups to promote education for incarcerated persons. This information can be of value to community-based non-profit organizations seeking to employ college educated formerly incarcerated people interested in human services careers. This research also provides a voice for ex-offenders who are most often the subject of research without the opportunity of direct input.

The State of New Jersey's recidivism rate mirrors the national trend as $65 \%$ of formerly incarcerated citizens return to prison within three years of release. While the U.S. has only $5 \%$ of the world's population, it holds approximately $25 \%$ of the world's incarcerated persons. No other country imprisons people at such a high rate [8]. The expansion of prisons and increased numbers of incarcerated people occurred after the passage of the Civil Rights Act of 1964 when public debate shifted from racial segregation to crime [4]. Income inequality and poverty during the 1970s and '80s led to increased crime rates across the country. Legislators responded with harsher prison sentences and the construction of more prisons. This overreliance on prisons to resolve social problems, coupled with their disparate impact on minorities, has made incarceration a normal life event in many communities, (Center for Prison Education, n.d.).

The negative consequences of mass incarceration extend beyond the individual inmate. Harsh criminal-justice policies have thrown America's poorest neighborhoods into chaos [9]. The probability that a family experiences poverty increases by nearly $40 \%$ while a father is incarcerated [7]. Children of incarcerated parents are at greater risk of developmental delays, behavioral problems, academic failure, and becoming incarcerated themselves [6]. Scholars are just beginning to explore the unintended, adverse consequences of mass incarceration upon disenfranchised communities [10].

\section{Purpose of this Qualitative Study}

The purpose of this qualitative study was to research the impact of a New Jersey-based college-in-prison program on 12 former inmates. Seven New Jersey-based correctional facilities offer accredited college courses to incarcerated people. This study concentrated on the college program at East Jersey State Prison in Rahway, NJ. Central to this dissertation study were the following research questions:

1. What influence do college-in-prison programs have on returning citizens' job attainment abilities?

2. What influence do college-in-prison programs have on returning citizens' recidivism?

3. What influence do college-in-prison programs have on returning citizens' abilities to provide for themselves?

4. What influence do college-in-prison programs have on returning citizens' families?

Participants were considered representative of the overall enrollment of incarcerated people in college courses. Eight of the former NJ STEP students were Afro-American, 2 were Hispanic and 2 were Caucasian. Three of the men are from ages 31-39, four are from ages ranging from 40-45, three are from ages 46-49, one is from ages 50-55, and one is from the ages 60-65 years. The identities of study participants were kept confidential and known only to the researcher. The participants qualified for this study by earning the educational benchmark of at least 30 credits in the NJ STEP program, are employed and have been out of prison for at least 6 months. The interviews occurred between July and October 2018.

The individual interviews provided data, which, when coded, exhibited the following common themes.

\section{Theme 1: Reducing stigma}

Incarcerated people have been removed from their community and issued standardized identifiable clothing and a number for identification. The individual has been formally labeled, stigmatized, and ostracized by society. Labeling Theory states that once a person is formally stigmatized, they may internalize the negative stereotypical image and conform to the anti-social behavior projected upon them. As an inmate's date of release from prison approaches, the anticipation of being ostracized by society can led to depression, fear, and anxiety. The labels ex-offender and ex-convict become the individual's identifying factor.

This study showed that the respect of having earned college credits or a college degree allows former student inmates to pivot attention away from their past imprisonment. Research 
participants exhibited a sense of relief as they recounted the positive reception, they received among family members, employers, coworkers, fellow college students, and professors for their academic accomplishments while in the college-in-prison program. NJ STEP program provides a foundation for student inmates to be accepted back into their communities at a level of respect they had not previously envisioned. All 12 research participants are continuing their educational pursuits towards a bachelor's or master's degree.

\section{Theme 2: Increasing social capital}

Social Capital is defined as a network of human relationships that empower one to advance in society [11]. Isolated from society, an incarcerated person's ability to develop contacts with people who can provide him or her with opportunities upon release to society are few or non-existent. NJ STEP students are able to develop relationships with educators and other professionals who may assist during their transition back into society. Many research participants detailed how the networks they developed while in the NJ STEP helped them acquire student loans, scholarships, housing and employment.

\section{Theme 3: Enhanced critical thinking and communication skills}

All 12 participants indicated their college education enhanced their critical thinking and communication skills. A person's vocabulary and communication skills can impact first impressions and careers [12]. Enhancing critical thinking and communication skills are essential to reducing stigma and establishing social capital. Disparities in vocabulary and literacy are associated with poverty, finding and retaining employment, supporting the education of children, and participating in communities [11].

Respondents reported that, prior to their college experience, their reaction to situations were more emotional than analytical. The 12 research participants related that the rigors of college academics, such as reading, researching data, interpreting information, writing papers, debating opposing concepts, and oral presentations increased their critical thinking skills and vocabulary. All 12 participants are engaged in youth mentoring, environmental preservation, or advocacy for social justice reforms, which require advanced communication skills.

This study also indicated that participants changed their leisure activities, reducing the amount of television they watched in favor of reading and engaging in conversations concerning concepts they had learned as opposed to generalized, day-to-day matter.

\section{Theme 4: Civic engagement}

All 12 participants cited involvement in community engagement activities, including: helping youths at-risk of becoming incarcerated; speaking at community events; and, being panelists at conferences advocating criminal justice reforms.

The data cited in this study points to a "normalization of incarceration," incarceration as a perverse "rite of passage" among many youths within disenfranchised communities across our nation.
As one participant explained, "One of my classes...gave us the book, The New Jim Crow" we spoke (about) the whole mass incarceration situation. And just really understanding it. Understanding, because where I grew up at, it means nothing for a young, Black poor man to go to prison. You know, it's part of what's more than likely going to be his outcome".

The data collected in this study indicates a desire by former student inmates to use their academic credentials and life experiences to improve the quality of life in their neighborhoods.

One interviewee related, "I've done mentoring at XXX high school. I've spoken at numerous events [on] a documentary, the 13th. I'm part of the Truth, Racial and Healing Transformation [program] at XXX University. [I] got invited to speak at XXX county college. That will be big."

Another former NJ STEP student said, "I see a lot of programs who target youth. Being that I came from that and that I was in their shoes, and they see themselves when they look at me, and I see myself when I look at them. But now, I bring this other perspective, and tell them about education and policy and the things I've learned that motivated me to want to be better and [say] 'You can learn this, too."'

From college and university campuses, to churches and local events, to mentoring programs, to public forums with legislators, the students of NJ STEP are involved in civic activities to promote youth development, criminal justice reforms, voting restoration rights for returning citizens, and healthier communities in New Jersey.

\section{Theme 5: Increased sense of self-worth and confidence}

All 12 participants are continuing their pursuits of higher education and still set aside time to be involved in work to help others and to change policies that negatively impact their communities. The men expressed gratitude for receiving the opportunity to earn a college degree and an increased sense selfpride in their academic accomplishments.

The second participant interviewed stated, "People were very surprised as far as what I was able to accomplish in prison as far as college. I already earned my associates in prison and graduated with a 3.9 GPA. Employers were very impressed with that."

Another participant stated, "I'm constantly told, "Congratulations, we're proud of you, keep doing good work. Your story is so great, I wish you can talk to my son for me,' and things like that."

The participants expressed an increased sense of self-worth as family members and friends sought their advice and counsel on personal issues. Others said their new role as a college student inspired family members to pursue or complete their education.

\section{Conclusion}

The purpose of this study was to access the impact of collegein-prison education on formerly incarcerated men of East Jersey 
State Prison, NJ. The idea of incarcerated people receiving free college courses has incited emotionally heated condemnations within the general public and some legislative bodies. Many argue that law abiding college students have tuition to pay and inmates are unworthy of such opportunities at no cost. Often, opinions and social policies are formulated on the basis of emotions as opposed to studying data [13]. This researcher hopes that this dissertation can be used to advance policies based upon its data and evidence.

This study's four research questions addressed the impact of college in prison education on the lives of former NJ STEP students at East Jersey State Prison, NJ. The questions are rooted into the foundations of the several key social indicators that determine the quality of life in communities: education; employment; public safety; and healthy family relations $[14,15]$.

The stigma of having a criminal record is a major barrier to securing employment. During job interviews, formerly incarcerated students are able to reduce stigma by pivoting attention away from their past and focusing on their academic accomplishments. College education bestows status in society, and employers use these credentials to sort potential job applicants [13].

\section{Theme 1 clearly applies concerning a former inmate's ability to obtain employment?}

Successful job interviews require critical thinking and effective communication skills. A person's vocabulary and communication skills can impact first impressions [12]. NJ STEP classroom activities included mock job interviews and peer group analyses. Due to their enhanced social capital, former inmates can present potential employers with impressive letters of recommendation from university professors and administrators. These factors reflect Themes 2 and 3 - increasing social capital and enhancement of critical thinking and communication skills.

\section{What influence do college-in-prison programs have on returning citizens' recidivism?}

In addition to the findings related to research question 1, participants experienced positive feelings of self-worth and confidence such that they would never return to prison. All participants felt confident they would not disappoint their professors, fellow students, and families. They were confident in their ability to be academically successful, law-abiding citizens.

All participants are engaged in civic activities. Returning citizens involved in civic engagement activities improve their selfworth, personal dignity, and public image. These connections to their communities reduce the chances of recidivism Bazemore and Stinchomb 2004. Themes 4 and 5 address this research question.

\section{What influences do college-in-prison programs have on returning citizens' abilities to provide for themselves?}

A college education is a key credential used by employers to sort job seekers [13]. Although a college education and the social capital to obtain recommendations may have helped some former inmates obtain a job or housing, critical thinking and communications skills were important for retaining them. The research participants were knowledgeable of what constitutes proper behavior in the work environment. They were also empathic with the responsibilities of being a business owner and manager. Several former NJ STEP students explained how their volunteer civic engagement activities led to job offers. Themes 2, 3, and 4 relate to this research question.

\section{What influence do college-in-prison programs have on returning citizens' families?}

College-in-prison program participants became an immediate source of hope and pride for their family members. They now claim the label of college student as opposed to convict. Hence, stigma was reduced both for the incarcerated people and their families.

As NJ STEP students earned more college credits, their sense of self-worth and confidence increased as well. Each course improved their critical thinking and communication skills. Participants reported their letters and conversations during visitations with loved ones centered upon subjects they were studying in class. Participants further urged their families to begin or finish their education and became role models and advisers within their families.

Also, of note, several formerly incarcerated student expressed that the college-in-prison program, NJ STEP, changed the culture of the institution. Education "transformed prison into a university, literally...guys are talking about Socrates! They're arguing about philosophy on a prison yard, in the showers. You will have a guy, having an argument, he'll run and get a book and come back out there to show you something. It (prison) turned into a campus. The whole prison-whoever is not in college---is in the GED program now, and guys in the college program are tutoring the guys in the GED program, so the whole prison is working together."

The problems associated with mass incarceration and recidivism will not be resolved solely through college-in-prison education. Social policies must address root issues of economic, racial and gender inequalities in American society. However, public and private sources of support for college-in-prison programs are a cost effective strategy which positively impact the lives of those incarcerated, their families and disenfranchised communities.

\section{Acknowledgment}

Sanford Sandy Shevack, Ed.D, teaches Sociology courses at Montclair State University, William Paterson University, Ramapo College, and Bergen Community College. He volunteers much of his time to Bella Chanel Mentoring Program of Passaic, NJ, the Mahwah Environmental Volunteer Organization and the IMPACT Repertory Theatre of Harlem.

\section{Conflict of Interest}

No conflict of interest.

\section{References}

1. Karpowitz, D (2017) College in prison. New Brinsmick, Rutgers University Press, New Jersey, United States. 
2. Mann K (2015) A nation behind bars. Against the Current, (185). The New Press, New York, USA, pp. 1-246.

3. Ballantine J, Roberts $K$, Korgen K (2018) Our social world ( $6^{\text {th }}$ Edn). Thousand Oaks, CA: Sage Publishing, California, USA.

4. Alexander M (2010) The new Jim Crow: Mass incarceration in the age of colorblindness. NY: The New Press, New York, USA.

5. (2015) Talk poverty New Jersey, USA.

6. Neyfakh L (2015) Throw the book at them. Slate.

7. Furman J, Holtz Eakin D (2016) Why mass incarceration doesn't pay. The New York Times, p.29.

8. Shermer A (2012) The relationship between prison-based educational programs and recidivism. pp. 1-18.

9. Thompson H (2014) Inner-city violence in the age of mass incarceration. The Atlantic.
10. Brown TN, Patterson E (2016) Criminal justice: Wounds from incarceration that never heal. The Conversation, Texas, USA.

11. Leon Guerro A (2014) Social problems: community, policy and social action. CA: Sage Publications, Los Angeles, California.

12. Marie Kerr S (2017) How literacy levels can impact your career. World Education Service, Canada.

13. Schaefer RT (2016) Sociology in modules. NY: McGraw-Hill, New York, USA.

14. Land K, Michalos A, Sirgy J (2012) Handbook of social indicators and quality of life research. Springer, Spain.

15. Why college in prison? Center for Prison Education, Middletown, CT: Wesleyman University, USA. 